\title{
Дарина БІЛА
}

\section{ПІДХОДИ ДО ІДЕНТИФІКАЦІї СТРАХОВИХ ГРУП}

Досліджена зарубіжна практика ідентифрікації страхових груп, передумови виокремлення IAIS поняття "міжнародна страхова група" та перелік критеріїв для проведення ідентифрікації страхової групи. Розглянуто підходи до утворення фрінансових груп. Проаналізовано активність страхових груп на ринку України та розкрито їх склад. Наведено недоліки розробленого Нацкомфінпослуг підходу до віднесення компаній до небанківських фрінансових груп, запропоновано доповнення до ідентифрікаційних ознак та пропозиції щодо забезпечення інформаційної прозорості діяльності страхових груп.

Ключові слова: міжнародна страхова група, страхова група, фрінансова група, критерії ідентифрікації, консолідований нагляд, регулювання.

\section{Дарина БЕЛАЯ}

\section{Подходы к идентификации страховых групп}

Исследованы зарубежные практики идентификации страховых групп, предпосылки выделения IAIS понятие "международная страховая группа" и перечень критериев для проведения идентификации страховой группы. Рассмотрены подходы к созданию фринансовых групп. Проанализирована активность страховых групп на рынке Украины и раскрыт их состав. Приведены недостатки разработанного Нацкомсринуслуг подхода к отнесению компаний к небанковским фринансовым группам, предложены дополнения к идентифрикационным признакам и предложения по обеспечению информационной прозрачности деятельности страховых групп.

Ключевые слова: международная страховая группа, страховая группа, финансовая группа, критерии идентификации, консолидированный надзор, регулирование.

\section{Daryna BILA}

\section{Approaches to identifying insurance groups}

Introduction. The insurance group existence in the market and risks that are associated with insurance groups' activities are led to the urgency of scientific research and determining the approaches to identify the insurance groups in Ukraine.

Purpose. To study the international experience and national practice of the insurance groups identification and the insurance groups' impact estimation on the insurance market.

Results. The article analyzes the foreign practice of the insurance groups identification, the background of the IAIS emphasize the concept of "international insurance group" and the list of the insurance group identification criteria. The author examined the financial group creation ap-

() Дарина Біла, 2017 
proaches: permissive, mixed, separate; and the insurance group identity indicators in Ukraine that are adopted by the National Commission for the Financial Service Markets Regulation of Ukraine.

Author revealed the presence of insurance groups in the domestic insurance market that are controlled by international financial conglomerates; analyzed the insurance groups' activity in Ukrainian market and studied their composition. The article contains the list of the insurance group performance indicators that are provided by the regulator; discloses the approach drawbacks that is developed by the National Commission for the Financial Service Markets Regulation for classifying companies as non-bank financial groups.

Conclusion. The author formed the proposals that are aimed at improving transparency in the insurance market of Ukraine, such as: publication of information about the implementation of non-bank financial group of the regulatory requirements for regulatory capital adequacy. The article illuminates the financial performance indicators information of non-bank financial groups.

Keywords: international insurance group, insurance group, financial group, identification criteria, consolidated supervision, regulation.

JEL Classification: G22.

Постановка проблеми. Міжнародна економічна інтеграція все більше впливає на страхову галузь, яка набуває глобального характеру. Тенденція до консолідації міжнародного страхового ринку, як наслідок потреби зростання, найбільш активно виявляється в секторах ринку, які розвиваються, оскільки в них умови для експансії найбільш сприятливі і не вичерпані [1, с. 114].

Страховики, завойовуючи частку ринку, створюють дочірні компанії, відкривають філії на національному рівні та поза межами юрисдикцій, перетворюючись у страхову групу. Глобалізації у страхуванні сприяє також низка законодавчих змін як на рівні окремих держав, державних об'єднань:

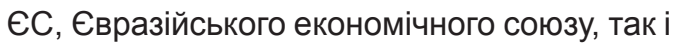
на всесвітньому рівні.

У зміцнення стійкості страхового ринку та глобальної фінансової системи свій внесок робить і Міжнародна асоціація страхових наглядів (IAIS), розробляючи принципи й інструменти регулювання міжнародних страхових груп, які можуть нести специфічні загрози для глобальної та національної економік, оскільки під час розширення об- сягів діяльності страхової групи та її активів можливі загрози виникнення неконтрольованих фрінансових ризиків і зловживань.

Страховий ринок України також $є$ вельми привабливим регіоном для експансії капіталу, особливо після 2013 року, коли набули чинності законодавчі зміни щодо усунення бар'єрів для іноземних страховиків. В країні здійснюється дерегуляція ринку, яка полегшує діяльність страховиків, зменшує матеріальні та часові витрати на спілкування з регулятором та іншими державними установами.

Водночас, діяльність на теренах України страхових компаній з іноземним капіталом, які належать до глобальних системо значущих фрінансових інститутів, у разі їх фінансових негараздів може нести загрози національному ринку. Наявність на страховому ринку великих організацій зумовила необхідність зміни векторів регулювання. Зокрема, виникла об'єктивна потреба у формуванні критеріїв і показників визначення страхових груп.

Мета статті полягає у вивченні світового досвіду та національної практики іденти- 
фрікації страхових груп, оцінки їх впливу на страховий ринок.

Аналіз останніх досліджень і публікацій. Інтеграційні процеси на страховому ринку досліджували як зарубіжні, так і українські науковці, а саме: О. Жегалова [1], О. Залєтов [2], А. Єпіфанов [3], Л. Нечипорук [4], Ф. Павелка [3], І. Школьник [3].

Віддаючи належне існуючим напрацюванням, залишаються дискусійними питаннями стосовно визначення показників виокремлення небанківських фрінансових груп і рівня прозорості їх діяльності. Це обумовлює важливість проведення цього наукового дослідження.

Виклад основного матеріалу дослідження. Формування фрінансових конгломератів має давню історію, проте до останнього десятиліття $\mathrm{XX}$ століття існували правові перепони, що стримували стрімкий ріст та розповсюдження цих структур.

За даними звіту "Регулювання фрінансових конгломератів" 1995 р. [5], дерегуляція національних фінансових ринків за останні десятиліття разом 3 інтернаціоналізацією фінансових ринків призвели до появи нових способів і засобів ведення бізнесу в умовах жорсткої конкуренції та інтегрованої світової економіки у 1980-х і 1990-х рр. З'явилися фрінансові конгломерати, часто зі значно великими балансами (і позабалансовими позиціями), що надають широкий спектр фрінансових послуг у різних географічних точках.

Термін “фрінансовий конгломерат” в вищенаведеному звіті використовується для позначення "будь-якої групи компаній під загальним контролем, виключна або переважна діяльність якої охоплює надання послуг принаймні в двох різних фрінансових секторах (банки, цінні папери, страхування)".

Сучасна структура об'єднань, що працюють на страховому ринку, знайшла відображення у визначенні міжнародної стра- хової групи, яка надана IAIS. Міжнародною страховою групою може бути:

- страхова група, яка здійснює тільки страхову діяльність;

- фрінансовий конгломерат, який охоплює й інші фінансові інститути, але переважаючою є страхова діяльність;

- частина фрінансового конгломерату, в якому переважають нестрахові фрінансові інститути;

- частина диверсифрікованого конгломерату, у т. ч. нефрінансові компанії.

Страхові компанії, що не мають дочірніх структур, але ведуть діяльність у різних юрисдикціях на базі фріліальної мережі та відповідають критеріям визначеним IAIS, також вважаються міжнародними страховими групами [6].

За методологією Організації Об'єднаних Націй, про міжнародний статус компанії, передусім, свідчить розмір відсотка ії̈ продажів за межами країни розташування материнської компанії, а також структура її активів [3, с. 128].

Міжнародною асоціацією страхових наглядів враховано підходи вказаної методології для визначення міжнародних страхових груп. Поняття міжнародної страхової групи та критерії її ідентифрікації ссрормовані в документі "Загальні засади нагляду за міжнародними страховими групами" [6].

Критерії ідентифрікації міжнародної страхової групи, які сформовані IAIS, подані в табл. 1.

Процес офріційного визнання об'єднань лежить у правовому полі, яке або дає можливість для створення фрінансової групи, або ускладнює цей процес. Існують три підходи до утворення фрінансових груп: 1) дозвільний; 2) самостійний; 3) змішаний [7].

Дозвільний характер утворення страхових груп характерний для страхового ринку Республіки Казахстан, де орган нагляду на основі аналізу поданих заявником докумен- 
Критерії ідентифікації міжнародної страхової групи*

\begin{tabular}{|c|c|c|c|c|}
\hline \multirow{2}{*}{ Критерій } & \multirow{2}{*}{$\begin{array}{l}\text { Субкритерій / } \\
\text { його значення }\end{array}$} & \multirow{2}{*}{ Показник } & \multicolumn{2}{|c|}{ Значення показника } \\
\hline & & & $\%$ & млрд. доларів США \\
\hline \multirow{2}{*}{$\begin{array}{l}\text { Міжнародна } \\
\text { діяльність }\end{array}$} & \multirow{2}{*}{$\begin{array}{c}\text { Кількість } \\
\text { юрисдикцій / } \geq 3\end{array}$} & $\begin{array}{c}\text { Валові премій, зібрані за } \\
\text { межами країни - реєстрації }\end{array}$ & \multirow[t]{2}{*}{$\geq 10$} & \multirow[t]{2}{*}{-} \\
\hline & & Сукупні валові премії групи & & \\
\hline \multirow{2}{*}{$\begin{array}{l}\text { Масштаб } \\
\text { діяльності }\end{array}$} & \multirow{2}{*}{$\begin{array}{c}\text { Фінансовий період / } \\
\text { останні } 3 \text { роки }\end{array}$} & $\begin{array}{c}\text { Середній обсяг активів } \\
\text { або }\end{array}$ & - & $\geq 50$ \\
\hline & & валові премії & - & $\geq 10$ \\
\hline
\end{tabular}

* Складено на основі [6].

тів вирішує питання щодо можливості формування групи та в разі позитивного рішення - надає згоду на її створення. Регулятор визначає можливість заявника виконувати групові нормативні вимоги, а також можливість сорормувати систему управління ризиками і підтримувати систему внутрішнього контролю усіх учасників групи.

Україна тяжіє до змішаного підходу до визнання страхової групи: на основі самостійного подання інформації про створення або регулятор приймає рішення про ідентифікацію групи на основі наглядових суджень. Практика ідентифрікації страхової групи з'явилась у правовому полі після прийняття розпорядження Нацкомфрінпослуг від 12.11.2015 р. № 2724, яким затверджено “Положення про порядок нагляду на консолідованій основі за небанківськими фрінан- совими групами, переважна діяльність у яких здійснюється фрінансовими установами, нагляд за якими здійснює Національна комісія, що здійснює державне регулювання у сфері ринків фрінансових послуг" [8].

Відповідно до змісту зазначеного положення варто виокремити два показники ідентифікації небанківських фрінансових груп, які можуть поділятися регулятором на страхові та кредитно-інвестиційні - це кількість компаній, які входять до складу групи, та розмір їх активів. Визначено також звітний період, який враховується при розрахунку активів та мінімальну межу зазначених показників (табл. 2).

Результати порівняльного аналізу ідентифрікації страхових груп в Україні та міжнародних страхових груп дали змогу зробити наступні висновки.

\section{Показники ідентифрікації страхових груп в Україні*}

Таблиця 2

\begin{tabular}{|c|c|c|}
\hline Показник & Визначення & Вага, \% \\
\hline $\begin{array}{l}\text { Кількість } \\
\text { установ }\end{array}$ & $\begin{array}{l}\text { Група юридичних осіб, які мають спільного контролера (крім банку), склада- } \\
\text { ється з } 22 \text { фрінансових установ. }\end{array}$ & \\
\hline \multirow[b]{2}{*}{ Активи } & $\begin{array}{l}\text { Середньоарифметичне значення активів за останні чотири звітні квартали небан- } \\
\text { ківської фінансової установи до сукупного розміру середньоарифметичних зна- } \\
\text { чень активів усіх фінансових установ, що належать до цієї групи, за цей період. }\end{array}$ & $\geq 50$ \\
\hline & $\begin{array}{l}\text { Середньоарифметичне значення активів за останні чотири звітні квартали фі- } \\
\text { нансових установ, нагляд за якими здійснює Нацкомфінпослуг, до сукупного } \\
\text { розміру середньоарифметичних значень активів усіх небанківських фінансо- } \\
\text { вих установ, що належать до цієї групи, за цей період. }\end{array}$ & $\geq 50$ \\
\hline
\end{tabular}

${ }^{*}$ Складено на основі [8]. 
По-перше, в основу визначення страхової групи покладено поняття кількості: фрінансових установ, які належать до групи в Україні та юрисдикцій, в яких працює страхова група в міжнародній практиці, водночас, ні IAIS, ні національний регулятор не акцентують на цьому увагу, оскільки не виокремлюють цей критерій.

По-друге, як свідчать дані табл. 2, при ідентифікації страхових груп в Україні регулятор надає перевагу активам серед інших показників діяльності страховика, що відповідає підходам у міжнародній практиці. Не заперечуючи важливість активів, як показника ідентифікації страхової групи, дискусійним залишається як перелік показників, так і вага показника. Не зовсім зрозумілий підхід національного регулятора до визначення відносних показників активів та їх ваги всередині страхової групи. Особливо зважаючи на те, що для визнання страхової групи такою, нагляд на консолідованій основі за якою здійснює Нацкомфрінпослуг, група має відповідати одночасно всім переліченим в табл. 2 ознакам.

По-третє, страхові премії як один із основних показників діяльності страховиків не задіяно в ідентифрікацію страхової групи в Україні, разом з тим він активно використовується в міжнародній практиці для визначення активності страховика. Тому, на наш погляд, виявляється доречним доповнити методику ідентиорікації страхової групи показником “страхові премії”.
Станом на листопад 2016 р., через рік після прийняття Нацкомфінпослуг зазначеного вище Положення, в Україні оголошено про діяльність чотирьох небанківських фрінансових груп. Нацкомфрінпослуг оприлюднено інформацію про склад, контролерів та частку істотної участі в статутних капіталах учасників чотирьох небанківських фрінансових груп. Нацкомфінпослуг може ідентифікувати зазначені вище підгрупи, але у разі, якщо регулятор не здійснить цього, то відповідно до складу учасників групи можливо стверджувати, що визначено страхові групи (табл. 3).

Необхідно зазначити, що процес офріційного визнання страхових груп започаткували страховики з іноземним капіталом, які $є$ міжнародними страховими групами, а дві з них - Aха S.A. та GRAWE Group - фрінансовими конгломератами. Проте процес самовизначення страхових груп іде достатньо повільно. Таке твердження ґрунтується на інформації О. Залетова, який зазначав, що в 2012 році в Україні діяли 20 страхових груп, з яких 8 - переважно з іноземним капіталом, дві - зі змішаним і 10 - з українським, та на зазначену групу страховиків припало близько $40 \%$ обсягу страхових послуг [10].

Перелік страхових компанії України, що належать до страхової групи (табл. 4), сфрормовано на основі інформації про небанківську групу, яку представлено регулятору, а показники їх діяльності - на осно-

Таблиця 3

Перелік страхових груп, що підпадають під консолідований нагляд Найкомфінпослуг станом на листопад 2016 р.*

\begin{tabular}{|c|c|c||}
\hline \hline Назва материнської компанії & Країна розташування & Назва страхової групи в Україні \\
\hline \hline Vienna Insurance Group & Австрія & VIENNA INSURANCE GROUP UKRAINE \\
\hline \hline GRAWE Group & Австрія & Граве Україна \\
\hline \hline Axa S.A & Франція & Група АХA \\
\hline \hline UNIQA Group & Австрія & Уніка Україна \\
\hline
\end{tabular}

${ }^{*}$ Складено на основі [9]. 
Склад учасників страхових груп в Україні*

\begin{tabular}{|c|c|c|c|c|}
\hline $\begin{array}{l}\text { Страхова } \\
\text { група }\end{array}$ & $\begin{array}{c}\text { Страхові компанії, } \\
\text { що належать до групи }\end{array}$ & $\begin{array}{l}\text { Активи, } \\
\text { тис. грн. }\end{array}$ & \begin{tabular}{|l|} 
Валові пре- \\
мії, тис. грн.
\end{tabular} & $\begin{array}{c}\text { Чисті премії, } \\
\text { тис. грн. }\end{array}$ \\
\hline \multirow{4}{*}{$\begin{array}{c}\text { VIENNA } \\
\text { INSURANCE } \\
\text { GROUP } \\
\text { UKRAINE }\end{array}$} & ПрАТ “СК “Українська страхова група” & 625766,90 & 664676,30 & 601071,50 \\
\hline & $\begin{array}{l}\text { ПрАТ “Українська страхова компанія } \\
\text { "КНЯЖА ВІЄННА ІНШУРАНС ГРУП” }\end{array}$ & 375763,60 & 397274,80 & 331413,80 \\
\hline & $\begin{array}{l}\text { ПрАТ “ЮПІТЕР СТРАХУВАННЯ ЖИТТЯ } \\
\text { ВІЄННА ІНШУРАНС ГРУП” }\end{array}$ & 283081,00 & 73857,00 & 73270,00 \\
\hline & $\begin{array}{l}\text { ТДВ “СТРАХОВЕ ТОВАРИСТВО З ДОДАТКО- } \\
\text { ВОЮ ВІДПОВІДАЛЬНІСТЮ “ГЛОБУС” }\end{array}$ & 184188,00 & 171608,90 & 153502,00 \\
\hline \multicolumn{2}{|c|}{ Р Разом по групі } & 1468799,50 & 1307417,00 & 1159257,30 \\
\hline \multirow{2}{*}{ Граве Україна } & ПрАТ “ГРАВЕ УКРАЇНА Страхування життя” & 2185558,60 & 254254,70 & 215600,10 \\
\hline & ПрАТ “Страхова компанія “ГРАВЕ УКРАЇНА & 109846,00 & 52872,50 & 48699,00 \\
\hline \multicolumn{2}{|c|}{ Разом по групі } & 2295404,60 & 307127,20 & 264299,10 \\
\hline \multirow{2}{*}{ Група AXA } & ПрАТ “Страхова компанія “АХА Страхування” & 1233220,00 & 1089649,00 & 1041700,00 \\
\hline & ТДВ “СК “АХА Страхування життя” & 38566,00 & 10759,00 & 10759,00 \\
\hline \multicolumn{2}{|c|}{ Разом по групі } & 1271786,00 & 1100408,00 & 1052459,00 \\
\hline \multirow{2}{*}{ Уніка Україна } & ПрАТ “СК “УНІКА” & 969314,00 & 1008058,00 & 784033,00 \\
\hline & |ПрАТ “СК “УНІКА ЖИТТЯ” & 812744,00 & 262903,00 & 261917,00 \\
\hline \multicolumn{2}{|c|}{ Разом по групі } & 1782058,00 & 1270961,00 & 1045950,00 \\
\hline
\end{tabular}

${ }^{*}$ Складено на основі [11-20].

ві річної фрінансової звітності за 2015 р. Усі страховики, які належать до страхових груп, виконують вимоги п. 4 ст. 14 Закону України "Про бухгалтерський облік та фрінансову звітність в Україні" та п 2.7 "Порядку складання звітних даних страховиків", мають власні веб-сайти та оприлюднюють на них річну фінансову звітність.

Страхові групи, підконтрольні міжнародним фрінансовим гравцям, охоплюють як ринок ризикового страхування, так і страхування життя. Як зазначено в табл. 4, три групи представлені однією компанією на кожному сегменті ринку, а VIENNA INSURANCE GROUP UKRAINE об'єднує 3 компанії ризикового страхування та 1 страхування життя.

Активність діяльності страхових груп на страховому ринку України (табл. 5) збільшується, незважаючи на політичну нестабільність та економічні труднощі. Так, якщо у
2008 р. страхові компанії, які підконтрольні міжнародним фінансовим конгломератам, володіли дуже невеликими частками ринку, питома вага активів досліджених страхових компаній не перевищувала значення 1\% [3, с. 175], то в 2015 р. - дві страхові групи перевищили $2 \%$ бар'єр, одна група - наблизилась до 3\% межі, а одна - Граве Україна акумулює 3,78\% ринку. На кінець 2015 р. офріційно задекларовані страхові групи в Україні контролювали 11,23\% активів страхового ринку та $13,4 \%$ обсягів страхових послуг. Найбільшу частку обсягів страхових послуг акумулює VIENNA INSURANCE GROUP UKRAINE.

За показником "чисті страхові премії" страхові групи утримували 15,76\% ринку. Збільшення частки ринку за чистими преміями порівняно з обсягами страхових послуг обумовлено меншою часткою премій переданих у перестрахування у страхових гру- 
Активність страхових груп на страховому ринку України

\begin{tabular}{|c|c|c|c|c|c|c|}
\hline Страхова група & $\begin{array}{c}\text { Активи, } \\
\text { млн. грн. }\end{array}$ & $\%$ & $\begin{array}{c}\text { Валові премії, } \\
\text { млн. грн. }\end{array}$ & $\%$ & $\begin{array}{c}\text { Чисті премії, } \\
\text { млн. грн. }\end{array}$ & $\%$ \\
\hline $\begin{array}{l}\text { VIENNA INSURANCE } \\
\text { GROUP UKRAINE }\end{array}$ & 1468,80 & 2,42 & 1307,42 & 4,40 & 1159,26 & 5,19 \\
\hline Граве Україна & 2295,40 & 3,78 & 307,13 & 1,03 & 264,30 & 1,18 \\
\hline Група AXА & 1271,79 & 2,09 & 1100,41 & 3,70 & 1052,46 & 4,71 \\
\hline Уніка Україна & 1782,06 & 2,93 & 1270,96 & 4,27 & 1045,95 & 4,68 \\
\hline Всього по ринку & 60729,13 & 11,23 & 29736,02 & 13,40 & 22354,90 & 15,75 \\
\hline
\end{tabular}

пах (діапазон коливань від 4,36\% до 17,7\%, проти $24,82 \%$ в цілому по ринку) у зв'язку з можливістю акумулювати більші ризики.

Процес визначення й ідентифікації страхових груп на теренах України $є$ одним із кроків запровадження консолідованого нагляду за небанківським фінансовим ринком та побудовою нагляду відповідно до сучасних векторів реформування процесу регулювання страхового ринку. Національний регулятор передбачає контроль вимоги достатності регулятивного капіталу страхової групи. Достатність регулятивного капіталу відображає здатність страхової групи покривати непередбачені збитки та своєчасно і в повному обсязі розрахуватися за своїми зобов'язаннями перед страхувальниками. Достатність капіталу страхової групи розраховується на основі показників річної звітності і контролюється регулятором один раз на рік. Відповідно до Solvency II страховики повинні розраховувати мінімальний рівень капіталу щонайменше один раз на квартал і результати розрахунку повідомляти регулятору. Ми вважаємо, що запровадження контролю на річній основі - недостатньо ефективне, оскільки в умовах високої турбулентності суттєві зміни можуть статися протягом року. А регулятор через відсутність інформації не може вплинути на страховика, щоб той вжив заходів для відновлення показника достатності капіталу. Також регулятор мабуть не планує оприлюднення ви- конання небанківською фрінансовою групою вимоги щодо достатності регулятивного капіталу, оскільки про цей процес нічого не вказано у прийнятому Положенні.

Реалізуючи міжнародні вимоги щодо розкриття прозорості структури власності, регулятор вимагає, а страхова група розкриває власників і кінцевого бенефіціара своїх учасників. В разі зміни структури власності чи видів діяльності встановлені строки сповіщення про цю подію контролера групи (протягом 10 днів) та регулятора (30 днів).

Вважається, що внутрішньо групові операції суттєво впливають на учасника страхової групи. Той фракт, що страховик є частиною групи, змінює, іноді істотно, ступінь його ризику, його фрінансове становище, роль його управління і його стратегію бізнесу [10].

Для аналізу внутрішньогрупових операцій у складі консолідованої річної фрінансової звітності, яку подають до Нацкомфрінпослуг, передбачається додаткове розкриття, яке стосується вкладень кожного із учасників групи в статутні капітали інших учасників небанківської фрінансової групи, операцій взаємного кредитування, інвестицій (крім вкладень у статутні капітали), взаємних гарантів і страхових послуг.

Позитивним $€$ також додаткове розкриття перед регулятором основних показників діяльності групи, а саме: загальних активів, власного капіталу, фрінансового результату. Інформація групується в квартальному 
розрізі, щодо показника активів додатково розраховується середньоарифметичне значення активів за останні чотири звітних квартали, частка активів небанківських фрінансових установ у складі активів групи та частка активів небанківських фрінансових установ, нагляд за якими здійснює Нацкомфрінпослуг у складі активів групи.

Висновки. Безперечно, позитивним фрактором $€$ запровадження консолідованого нагляду за небанківськими фрінансовими групами та висвітлення регулятором їх складу, а саме сформованих страхових груп та оприлюднення власників істотної участі кожного учасника страхової групи і кінцевих власників істотної участі контролера страхової групи. Водночас, доцільним було б висвітлення регулятором виконання небанківською фрінансовою групою єдиної сфрормованої нормативної вимоги щодо ії діяльності: достатності регулятивного капіталу. Крім оприлюднення виконання вказаного нормативу страховою групою доцільно було б висвітлювати інфрормацію про фрінансові показники діяльності небанківських фрінансових груп. Доступ до вказаної інформації покращив би прозорість страхового ринку України.

\section{Список використаних джерел}

1. Жегалова Е.В. Развитие регулирования и надзора на мировом страховом рынке в условиях глобализации: зарубежный и российский опыт / Е.В. Жегалова // Экономические науки. 2015. - № 10 (131). - C. 113-116.

2. Залєтов О.М. Страхові групи: новий етап розвитку страхового ринку України / О.М. Залєтов // Страхова справа. - 2003. № 4 (12) - C. 58-61.

3. Інтеграційні процеси на фрінансовому ринку України : монографрія / за заг. ред. д-ра екон. наук А.О. Єпіфранова, д-ра екон. наук I.О. Школьник і д-ра екон. наук Ф. Павелки. Суми : ДВНЗ “УАБСНБУ”, 2012. - 258 с.
4. Нечипорук Л.В. До визначення поняття “страхова група" / Л.В. Нечипорук // Вісник Національного університету "Юридична академія України імені Ярослава Мудрого”. - 2003. № 4 (12). - C. 35-44.

5. The supervision of financial conglomerates / Tripartite Group of bank, securities, and insurance regulators. - 1995. - 119 p. [Electronic resource]. Access mode : http://www.bis.org/publ/bcbs20.pdf

6. Common framework for the supervision of internationally active insurance groups (Revised draft) / IAIS. - September 2014. [Electronic resource]. - Access mode : http://iaisweb.org/view/ element_href.cfm?src=1/23156.pdf

7. Тарасова О. Механизм консолидированного надзора за банковской деятельностью и его инструменты / О. Тарасова // Банкаускі веснік, чэрвень 2009. - Режим доступу : http:// www.nbrb.by/bv/articles/1608.pdf

8. Положення про порядок нагляду на консолідованій основі за небанківськими фрінансовими групами, переважна діяльність у яких здійснюється фрінансовими установами, нагляд за якими здійснює Національна комісія, що здійснює державне регулювання у сфрері ринків фрінансових послуг: Розпорядження Національної комісії, що здійснює державне регулювання у сфрері ринків фінансових послуг від 12.11.2015 № 2724 [Електронний ресурс]. - Режим доступу : http://zakon2. rada.gov.ua/laws/show/z1511-15/paran51\#n51

9. Небанківські фонансові групи. Станом на листопад 2016 р. / Нацкомфрінпослуг. [Електронний ресурс]. - Режим доступу : https://nfp. gov.ua/content/nebankivski-finansovi-grupi.html

10. На ТОП-20 страховых групп приходится около 40\% объема страховых услуг. Прессрелиз от 13.03.2013 г. [Електронний ресурс] // Мой страховой агент. - Режим доступу : http:// myagent.com.ua/analytics/text/215

11. Річна звітність / ПрАТ "СК "Українська страхова група". [Електронний ресурс]. - Peжим доступу : http://ukringroup.ua/ukr/about/ finance-info/annual_reports/ 


\section{АКТУАЛЬНІ ПИТАННЯ ТЕОРІЇ І ПРАКТИКИ ФІНАНСІВ}

12. Фінансова звітність за 2015 рік / ПрАТ "Українська страхова компанія "КНЯЖА ВІЄННА ІНШУРАНС ГРУП”. [Електронний ресурс]. Режим доступу : http://kniazha.com.ua/ua/ company/1333648844/1461756919/

13. Фінансова звітність [Електронний ресурс] / ПрАТ "ЮПІТЕР СТРАХУВАННЯ ЖИТТЯ ВІЄННА ІНШУРАНС ГРУП”. - Режим доступу : http://www.jupiter.com.ua/ua/about/finance/ financial_report/

14. Річна фрінансова звітність СК “Глобус" VIG [Електронний ресурс] / ТДВ "СТРАХОВЕ ТОВАРИСТВО З ДОДАТКОВОЮ ВІДПОВІДАЛЬНІСТЮ “ГЛОБУС”. - Режим доступу : http://icglobus.com/page-2204.html

15. Фінансові показники [Електронний ресурс] / ПрАТ "ГРАВЕ УКРАЇНА Страхування життя". - Режим доступу : http://www.grawe.ua/ ua/Download_life.htm\#1240-tab

16. Фінансові показники [Електронний ресурс] / ПрАТ "Страхова компанія "ГРАВЕ УКРАÏнA". - Режим доступу : http://www.grawe.ua/ua/ Download_risk.htm\#1763-tab

17. Фінансові звіти [Електронний ресурс] / ПрАТ "Страхова компанія "АХА Страхування". - Режим доступу : http://axa-ukraine.com/ company/axa-in-ukraine/finances/

18. Фінансова звітність [Електронний ресурс] / ТДВ “СК “АХА Страхування життя". - Режим доступу : http://hghltd.yandex.net/ yandbtm? fmode=inject\&url=http $\% 3 \mathrm{~A} \% 2 \mathrm{~F} \% 2 \mathrm{Fa}$ xa-life.com.ua\%2F\&tld=ua\&lang $=u k \& l a=148427$ $5712 \&$ tm $=1484768157 \&$ text $=\% D 0 \% A 2 \% D 0 \% 94$ $\% D 0 \% 92 \% 20 \% C 2 \% A B \% D 0 \% A 1 \% D 0 \% 9 A \% 20$ $\%$ C $2 \% A B \% D 0 \% 90 \% D 0 \% A 5 \% D 0 \% 90 \% 20$ $\% D 0 \% A 1 \% D 1 \% 82 \% D 1 \% 80 \% D 0 \% B 0 \% D 1 \% 85 \% D$ $1 \% 83 \% D 0 \% B 2 \% D 0 \% B 0 \% D 0 \% B D \% D 0 \% B D \% D 1$ $\% 8 F \% 20 \% D 0 \% 96 \% D 0 \% B 8 \% D 1 \% 82 \% D 1 \% 82 \% D$ $1 \% 8 \mathrm{~F} \% \mathrm{C} 2 \% \mathrm{BB} \& / 10 \mathrm{n}=\mathrm{ru} \& \mathrm{mime}=\mathrm{htm} / \& \operatorname{sign}=4 \mathrm{~b} 84 \mathrm{fC}$ 491d6407c2f92e91e97f6d909c\&keyno $=0$

19. Годовые отчеты [Электронный ресурс] / ПрАТ “СК "УНІКА”. - Режим доступа : https://uniqa.ua/about_us/about_company/
20. Годовые отчеты [Электронный ресурс] / ПрАТ “СК "УНІКА ЖИТТЯ”. - Режим доступа : https://uniqa.ua/about_us/about_company/

\section{References}

1. Zhegalova, E.V. (2015). Razvitie regulirovaniya i nadzora na mirovom strahovom rynke v usloviyah globalizatsii: zarubezhnyy i rossiyskiy opyt [The development of regulation and supervision on the world insurance market in the context of globalization: foreign and Russian experience]. Ekonomicheskie nauki - Economic science, 10 (131), 113-116 [in Russian].

2. Zalietov, O.M. (2003). Strakhovi hrupy: novyi etap rozvytku strakhovoho rynku Ukrainy [Insurance groups: new development stage of the Ukrainian insurance market]. Strakhova sprava - Insurance business, 4 (12), 58-61 [in Russian].

3. Yepifanov, A.O., Shkolnyk, I.O., Pavelka, F. (Eds.). (2012). Intehratsiini protsesy na finansovomu rynku Ukrainy [Integration processes in the financial market of Ukraine]. Sumy: DVNZ "UABSNBU" [in Ukrainian].

4. Nechyporuk, L.V. (2003). Do vyznachennia poniattia "strakhova hrupa" [By the definition of "insurance group"]. Visnyk Natsionalnoho universytetu "Yurydychna akademiia Ukrainy imeni Yaroslava Mudroho" - Yaroslav Mudryi Herald of National law university, 4 (12), 35-44 [in Ukrainian].

5. The supervision of financial conglomerates (1995). Tripartite Group of bank, securities, and insurance regulators. Available at: http://www.bis.org/ publ/bcbs20.pdf

6. Common framework for the supervision of internationally active insurance groups (Revised draft). IAIS (2014). Available at: http://iaisweb.org/ view/element_href.cfm?src=1/23156.pdf

7. Tarasova, O. (2009). Mehanizm konsolidirovannogo nadzora za bankovskoy deyatelnostyu i ego instrumenty [The mechanism of consolidated supervision over banking activities and its instruments]. Bankovskiy vesnik - Bank bulletin. Available at: http://www.nbrb.by/bv/articles/1608.pdf 


\section{АКТУАЛЬНІ ПИТАННЯ ТЕОРІЇ І ПРАКТИКИ ФІНАНСІВ}

8. Polozhennia pro poriadok nahliadu na konsolidovanii osnovi za nebankivskymy finansovymy hrupamy, perevazhna diialnist $u$ yakykh zdiisniuietsia finansovymy ustanovamy, nahliad za yakymy zdiisniuie Natsionalna komisiia, shcho zdiisniuie derzhavne rehuliuvannia u sferi rynkiv finansovykh posluh: Rozporiadzhennia Natsionalnoi komisii, shcho zdiisniuie derzhavne rehuliuvannia u sferi rynkiv finansovykh posluh vid 12.11.2015 № 2724. The National commission for the financial service markets regulation] (2015). Regulations on the procedure of supervision on a consolidated basis for non-Bank financial groups preferential activities in which are financial institutions that are being supervised by the National commission for the financial service markets regulation". Available at: http://zakon2.rada.gov. ua/laws/show/z1511-15/paran51\#n51.

9. Nebankivski finansovi hrupy. Stanom na lystopad 2016 r. (2016). [Non-bank financial group]. (2016, November). Available at: https://nfp.gov.ua/ content/nebankivski-finansovi-grupi.html

10. Na TOP-20 strahovyh grupp prihoditsja okolo $40 \%$ obiema strahovyh uslug. Press-reliz ot 13.03.2013. [TOP-20 insurance groups account for about $40 \%$ of the volume of insurance services. Press release]. (2013, March, 13). Available at: http://myagent.com.ua/analytics/text/215

11. Richna zvitnist. PrAT "SK "Ukrainska strakhova hrupa" [Annual reports PrAT "Insurance company "Ukrainian insurance group"]. Available at: http://ukringroup.ua/ukr/about/finance-info/annual_reports/

12. Finansova zvitnist za 2015 rik. PrAT “Ukrainska strakhova kompaniia "KNIaZhA VIleNNA INShURANS HRUP" [Finance statement for 2015. PrAT "Ukrainian insurance company "Kniazha Vienna Insurance Group"]. Available at: http://kniazha.com. ua/ua/company/1333648844/1461756919/

13. Finansova zvitnist. PrAT "IUPITER STRAKhUVANNIa ZhYTTIa VIIeNNA INShURANS HRUP" [Finance statement. PrAT "Jupiter life insurance Vienna Insurance Group"]. Available at: http://www.jupiter.com.ua/ua/about/finance/financial_report/
14. Richna finansova zvitnist SK "Hlobus" VIG / TDV "STRAKhOVE TOVARYSTVO Z DODATKOVOIU VIDPOVIDALNISTIU "HLOBUS" [Annual financial statements. TDV "Insurance Additional Liability Company "Globe"]. Available at: http://icglobus.com/page-2204.html

15. Finansovi pokaznyky. PrAT "HRAVE UKRAINA Strakhuvannia zhyttia" [Financial statements. PrAT "Grawe Ukraine Life insurance"]. Available at: http://www.grawe.ua/ua/Download life.htm\#1240-tab

16. Fnansovi pokaznyky. PrAT "Strakhova kompaniia "HRAVE UKRAINA" [Financial statements. PrAT "Insurance company "Grawe Ukraine"]. Available at: http://www.grawe.ua/ua/Download_risk. htm\#1763-tab

17. Finansovi zvity. PrAT "Strakhova kompaniia "AKhA Strakhuvannia" [Financial statements. PrAT "Insurance company "AXA Insurance"]. Available at: http://axa-ukraine.com/company/axa-inukraine/finances/

18. Finansova zvitnist. TDV "SK "AKhA Strakhuvannia zhyttia" [Financial statements. TDV "Insurance company "AXA Life insurance"]. Available at: http://hghltd.yandex.net/yandbtm ?fmode=inject\&url=http $\% 3 A \% 2 F \% 2$ Faxa-life. com.ua\%2F\&tld=ua\&lang =uk\&la=148427571 $2 \& t m=1484768157 \&$ text $=\% D 0 \% A 2 \% D 0 \% 94$ $\% D 0 \% 92 \% 20 \% C 2 \% A B \% D 0 \% A 1 \% D 0 \% 9 A \% 20$ $\%$ C $2 \% A B \% D 0 \% 90 \% D 0 \% A 5 \% D 0 \% 90 \% 20$ $\% D 0 \% A 1 \% D 1 \% 82 \% D 1 \% 80 \% D 0 \% B 0 \% D 1 \% 85 \%$ D1\%83\%D0\%B2\%D0\%B0\%D0\%BD\%D0\%BD\%D 1\%8F\%20\%D0\%96\%D0\%B8\%D1\%82\%D1\%82\% $D 1 \% 8 F \% C 2 \% B B \& / 10 n=r u \&$ mime $=h t m / \& s i g n=4 b 8$ 4fc491d6407c2f92e91e97f6d909c\&keyno=0

19. Godovyie otchety / PrAT "SK "UNIKA" [Annual report. PrAT "Insurance company "UNIQA"]. Available at: https://uniqa.ua/about_us/about_company/

20. Godovyie otchety / PrAT "SK "UNIKA ZhITTYa" [Annual report. PrAT "Insurance company "UNIQA Life"]. Available at: https://uniqa.ua/ about_us/about_company/

Стаття надійшла до редакції 14.02.2017. 